DOI: https://doi.org/10.24127/ajpm.v10i2.3538

\title{
THE EFFECT OF SELF-REGULATED LEARNING ON STUDENTS' PROBLEM-SOLVING ABILITIES
}

\author{
Sri Rahayuningsih ${ }^{1}$, Muhammad Hasbi ${ }^{2 *}$, Mulyati ${ }^{3}$, Muhammad Nurhusain ${ }^{4}$ \\ 1,3,4 STKIP YPUP, Makassar, Indonesia \\ ${ }^{2 *}$ Institut Agama Islam As'Adiyah Sengkang, Sengkang, Indonesia \\ *Corresponding author. Sengkang, Indonesia \\ E-mail: $\quad$ srirahayuningsih86@gmail.com ${ }^{1)}$ \\ muhammad.hasby80@gmail.com ${ }^{2 *}$ \\ mulyatiypup@gmail.com ${ }^{3}$ \\ zein.alhusain@gmail.com ${ }^{4}$
}

Received 06 February 2021; Received in revised form 14 June 2021; Accepted 01 July 2021

\begin{abstract}
The present study aimed to 1) investigate the effect of self-regulated learning on students' mathematical problem-solving ability; 2) describe the cognitive processes carried out by students with low and high selfregulation and high problem-solving ability. This study employed an explanatory mixed-method design. Nineteen students at a private high school, in Makassar, Indonesia, were selected, in order to complete the questionnaire, mathematical problem-solving ability test. Of the 19 students, two were selected as research subjects representing problem-solving ability. The quantitative data were analyzed using descriptive statistics and inferential statistics, while the qualitative data analysis had to go through the following stages including, reduction, data display, and conclusion drawing. The results showed that 1) self-regulated learning had no effect on students' mathematical ability; 2) the cognitive processes carried out by students with high selfregulation and high problem-solving ability included high literacy ability, high metacognitive awareness, being proactive yet inflexible; 3 ) the cognitive processes carried out by students with low self-regulation and high problem-solving ability included low literacy ability but showing more flexible attitudes. From this study, it can be concluded that problem-solving ability is not influenced by self-regulated learning, but by other factors such as the environment, cognitive ability and cognitive preparedness.
\end{abstract}

Keywords: Problem-solving ability; self-regulated learning.

\begin{abstract}
Penelitian ini bertujuan untuk 1) menginvestigasi pengaruh self-regulated learning terhadap kemampuan pemecahan masalah matematis siswa; 2) mendeskripsikan proses kognitif yang dilakukan siswa dengan selfregulation rendah dan tinggi dan kemampuan pemecahan masalah tinggi. Penelitian ini menggunakan explanatory mixed-method design. Sembilan belas siswa sekolah menengah swasta, di Makassar, Indonesia, dipilih untuk mengisi angket tes kemampuan pemecahan masalah matematika. Dari 19 siswa tersebut, dipilih dua orang sebagai subjek penelitian yang mewakili kemampuan pemecahan masalah. Data kuantitatif dianalisis menggunakan statistik deskriptif dan statistik inferensial, sedangkan analisis data kualitatif melalui tahapan yaitu, reduksi data, menampilkan data, penarikan Kesimpulan. Hasil penelitian menunjukkan bahwa 1) self-regulated learning tidak berpengaruh terhadap kemampuan matematika siswa; 2) proses kognitif yang dilakukan siswa dengan self-regulated learning tinggi dan kemampuan pemecahan masalah tinggi meliputi kemampuan literasi tinggi, kesadaran metakognitif tinggi, proaktif namun tidak fleksibel; 3) Proses kognitif yang dilakukan siswa dengan self-regulated learning rendah dan kemampuan pemecahan masalah tinggi meliputi kemampuan literasi rendah tetapi menunjukkan sikap lebih fleksibel. Dari penelitian ini dapat disimpulkan bahwa kemampuan pemecahan masalah tidak dipengaruhi oleh self-regulated learning, melainkan oleh faktor lain seperti lingkungan, kemampuan kognitif, dan kesiapan kognitif.
\end{abstract}

Keywords: Kemampuan pemecahan masalah, self-regulated learning.

This is an open access article under the Creative Commons Attribution 4.0 International License 
DOI: https://doi.org/10.24127/ajpm.v10i2.3538

\section{INTRODUCTION}

Problem-solving is the most important part of a school curriculum in the STEM domain (science, technology, engineering, and mathematics) (Baars et al., 2017; Gog et al., 2020). Unfortunately, most students are only able to solve structured problems by following a series of actions that have been determined earlier. Students are accustomed to being limited by rules regarding actions that may or may not be taken to go from the initial state or A to the destination state or B (van Gog et al., 2020). When students solve a problem, they need procedural knowledge about what actions to take, how to do them and why they should take those actions (Gnaldi et al., 2020; Smith \& Mancy, 2018). A large number of studies inspired by cognitive load theory show that students are unable to obtain initial information effectively when faced with problem-solving (Kim et al., 2019), while in fact, initial information can help students identify the keywords needed to solve a problem (Hasbullah \& Sajiman, 2020; van Gog et al., 2020). When students are faced with problem-solving tasks, it is important that they can manage their own learning process adequately, especially when they have to undergo self-study sessions where the teacher is absent (Hacker \& Bol, 2019). Selfregulated learning is learning to selfregulate, monitor motivation and academic goals, manage human resources and their surroundings, be an actor in the decision-making process and executing the learning process (Cai et al., 2020). There are different models of self-regulated learning, but most of which describe self-regulated learning as a process that includes the preparation (planning), performance, and evaluation stages. Self-regulated learning also involves cognitive, behavioral, motivational, and affective processes in each phase (Panadero \& Brown, 2017). According to Gog et al. (2020), the self-regulated learning model emphasizes accurate selfmonitoring (assessing one's own performance level) and self-regulation (deciding how to proceed).

Self-regulated learning in research is defined as the ability to be an independent individual in the learning process in terms of metacognitive, motivational, and behavioral perspectives (Lai \& Hwang, 2016; van Gog et al., 2020). These three aspects consist of the following indicators: 1) From a metacognitive perspective, independent individuals plan, set goals, organize, monitor themselves, and evaluate themselves on various things during the process of gaining expertise; 2) From a motivational perspective, independent individuals are aware of their competence, show high selfconfidence in themselves (high selfefficacy), and show an interest in the task. 3) In terms of behavior, independent individuals choose, arrange, and create their own learning environment for optimal learning.

As a result of COVID-19, many countries require schools to suspend classroom learning to stop the spread of the virus, which is a challenge for schools with 370 million students worldwide by UNESCO (OwusuFordjour et al., 2020). It should be noted that long-term isolation has created many difficulties for students in online learning. Among them, students experience stress (Violanti et al., 2018). In particular, COVID-19 seriously threatens student health and causes anxiety and depression, which can affect the learning process of isolated students at home (Li et al., 2020; Özdin 
\& Bayrak Özdin, 2020). Negative emotions such as anxiety can affect students' psychological and academic progress (Pascoe et al., 2020; Pekrun, 2017). The involvement and interaction between teachers and students during online learning is very important for students to build an understanding of new knowledge (Lo \& Hew, 2020). However, distance learning results in poor interaction and low learning outcomes during epidemics. All of the above problems need to be addressed immediately to improve student learning processes and outcomes during the pandemic (Xiantong et al., 2019).

Self-regulated learning is crucial during a pandemic like today, because it allows students to develop the ability to regulate and direct themselves, adjust and control themselves, especially in solving problems (Cai et al., 2020). According to Cai et al. (2020), students are asked to be able to organize themselves in learning during the COVID-19 pandemic. Besides, students must also be able to plan their own learning activities and manage their time wisely so that they can have a regular learning schedule.

Preliminary studies suggest that mathematics learning at SMA YP PGRI 3 Makassar during the COVID-19 pandemic was not very effective in helping students solve mathematical problems online. It was difficult for the students to understand the information delivered by the teacher. Interview with one of the mathematics teachers from SMA YP PGRI 3 has also revealed that the majority of the students were unable to conduct self-regulated learning although online learning requires them to possess the ability to regulate self. As a result, the students had poor learning performance, especially in solving mathematical problems. Assume that this problem might root from student poor self-regulation of learning. Therefore, considering the importance of self-regulated learning in improving students' problem-solving ability, this study was designed to 1) investigate the effect of self-regulated learning on students' mathematical problem-solving ability; 2) describe the cognitive processes carried out by students with low and high self-regulation and high problem-solving ability.

\section{METHODS}

This study used a mixed-method design combining the qualitative and quantitative data collection and analysis (Creswell, 2017). The approach used to analyzing the data was explanatory where quantitative data analysis was followed by qualitative data analysis (Creswell, 2017). The quantitative data were collected to describe the correlation between self-regulated learning and students' mathematical problem-solving ability at SMA YP PGRI 3 Makassar. Meanwhile, the qualitative data were obtained to explore the students' ability to solve mathematical problems based on selfregulated learning. The population of this study wasthe eleven-grade students from SMA YP PGRI 3 Makassar, while the sample contained 19 students from XI IPA. Of the 19 students, two were selected as research subjects representing problem-solving ability.

Due to the corona virus outbreak, the data collection was done online. The data was collected through a survey, tests and interviews. The questionnaire used in the survey was a close-ended questionnaire. A test was developed to measure the participants' ability to solve mathematical problems. In this study, the test contained geometry problem-solving tasks. 
DOI: https://doi.org/10.24127/ajpm.v10i2.3538

The quantitative data were analyzed using descriptive statistics and inferential statistics, while the qualitative data analysis had to go through the following stages: 1) Data reduction; 2) Data Display; 3) Conclusion Drawing/Verification. The research hypotheses were examined using a simple regression technique. The hypothesis testing was done to investigate the effect of self-regulated learning (independent variable, $\mathrm{X}$ ) on students' mathematical problem-solving ability (dependent variable, Y). The statistics hypotheses used in this study were presented as follows:

$\mathrm{H} 0: \rho \leq 0$

(Self-regulated learning had no positive effect on student' mathematical problem-solving ability at YP PGRI 3 Makassar)

$\mathrm{H} 1: \rho>0$

(Self-regulated learning had a positive effect on student' mathematical problem-solving ability at YP PGRI 3 Makassar)
Further investigation was carried out on the thinking processes of participants who obtained good scores from the test. Two subjects were selected to reveal their thought processes in solving geometric problems. The selected subjects had high test scores, were in the high selfregulation and low self-regulation category. One male student was selected to represent the participants with high problem-solving ability and high selfregulation and one female student was selected to represent the participants with high problem-solving ability but low self-regulation.

\section{RESULTS AND DISCUSSION}

Prior to conducting the correlation and regression tests, test of normality was performed. The normality test was done to ensure that the data were distributed normally. The results is presented in Table 1.

Table 1. The result of normality test on self-regulated learning and mathematical problem-solving ability

\begin{tabular}{lcccccc}
\hline \multicolumn{9}{c}{ Tests of Normality } \\
\hline & \multicolumn{4}{c}{ Kolmogorov-Smirnov } & \multicolumn{4}{c}{ Shapiro-Wilk } \\
\cline { 2 - 7 } & Statistic & Df & Sig. & Statistic & Df & Sig. \\
\hline Self-Regulated Learning & .189 & 19 & .071 & .907 & 19 & .066 \\
Mathematical Problem- & .248 & 19 & .003 & .907 & 19 & .064 \\
Solving Ability & .24 & 19 & & & &
\end{tabular}

In the Table 1 Lilliefors significance correction analysis, the significance values of self-regulated learning and problem-solving ability can be seen in the Shappiro Wilk's column. Since the value of the sample was 19, the significance of selfregulated learning was 0.066 and the significance of problem-solving ability was 0.064 . These figures suggest that the data were distributed normally. So, this data were accepted to continue to the next test. To investigate the significance of the correlation between self-regulated learning and problemsolving ability, Pearson correlation testing with $\alpha=0.05$ was performed. The result of Pearson correlation test is presented in Table 2. 
DOI: https://doi.org/10.24127/ajpm.v10i2.3538

Table 2. The correlation between self-regulated learning and mathematical problemsolving ability

\begin{tabular}{|c|c|c|c|c|c|c|c|}
\hline \multicolumn{8}{|c|}{ ANOVA Table } \\
\hline & & & $\begin{array}{l}\text { Sum of } \\
\text { Squares }\end{array}$ & df & $\begin{array}{l}\text { Mean } \\
\text { Square }\end{array}$ & $\mathrm{F}$ & Sig. \\
\hline \multirow{3}{*}{$\begin{array}{l}\text { Problem- } \\
\text { solving ability } \\
\text { * Self }\end{array}$} & Between & (Combined) & 563.491 & 13 & 43.345 & .435 & .894 \\
\hline & \multirow{2}{*}{ Groups } & Linearity & .147 & 1 & .147 & .001 & .971 \\
\hline & & $\begin{array}{l}\text { Deviation } \\
\text { from }\end{array}$ & 563.344 & 12 & 46.945 & .472 & .867 \\
\hline \multirow{3}{*}{$\begin{array}{l}\text { Regulated } \\
\text { Learning }\end{array}$} & & Linearity & & & & & \\
\hline & \multirow{2}{*}{\multicolumn{2}{|c|}{$\begin{array}{c}\text { Within Groups } \\
\text { Total }\end{array}$}} & 497.667 & 5 & 99.533 & & \\
\hline & & & 1061.158 & 18 & & & \\
\hline
\end{tabular}

Based on the analytical findings in table 2, the significance value obtained for the correlation was 0.867 , which is bigger than 0.05 ; thus, $\mathrm{H}_{0}$ was rejected and $\mathrm{H}_{1}$ was accepted. As a result, it can be said that self-regulated learning had a linear correlation with mathematical problem-solving ability.

A linear regression analysis was conducted to investigate the contribution of self-regulated learning on mathematical problem-solving ability. The analysis was performed to examine the direct effect of self- regulated learning on mathematical problem-solving ability. The hypothesis tested in this analysis was: "Selfregulated learning had an effect on students' mathematical problem-solving ability". This hypothesis was further formulated into $\mathrm{H} 0$ : Self-regulated learning had no effect on students' mathematical problem-solving ability and H1: Self-regulated learning had an effect on students' mathematical problem-solving ability. The result of the linear regression analysis is presented in Table 3.

Table 3. The result of the linear regression analysis on self-regulated learning and mathematical problem-solving ability

\begin{tabular}{|c|c|c|c|c|c|c|}
\hline \multirow{3}{*}{\multicolumn{2}{|c|}{ Model }} & \multicolumn{5}{|c|}{ Coefficients $^{\mathrm{a}}$} \\
\hline & & \multicolumn{2}{|c|}{$\begin{array}{l}\text { Non-standardized } \\
\text { Coefficients }\end{array}$} & \multirow{2}{*}{$\begin{array}{c}\text { Standardized } \\
\text { Coefficients } \\
\text { Beta }\end{array}$} & \multirow[t]{2}{*}{$\mathrm{t}$} & \multirow{2}{*}{ Sig. } \\
\hline & & B & Std. Error & & & \\
\hline \multirow[b]{2}{*}{1} & (Constant) & 52.768 & 9.297 & & 5.675 & .000 \\
\hline & $\begin{array}{l}\text { Self Regulated } \\
\text { Learning }\end{array}$ & .007 & .151 & .012 & .049 & .962 \\
\hline
\end{tabular}

Table 3 shows that $\hat{Y}=52.768+$ $0.007 \mathrm{X}$ and the significance value is $0.962>0.05$. The regression equation indicates that mathematical problemsolving ability is not determined by selfregulated learning, but by other factors. Since the significance value was 0.962 $>0.05, \mathrm{H}_{0}$ was accepted. Therefore, it can be said that self-regulated learning had no positive effect on eleven-grade students' mathematical problem-solving ability at SMA YP PGRI 3, Makassar. Furthermore, the analysis showed that self-regulation of students from SMA YP PGRI 3 can be categorized into medium $(36.84 \%)$, high $(36.84 \%)$, very high $(26.31 \%)$. In conclusion, the majority of the students had high self- 
regulation, which means that they were capable of managing self in performing their own academic and non-academic activities. However, the test result showed that 14 out of $19(73.68 \%)$ students from XI IPA SMA YP PGRI 3 had poor ability in solving geometry problems. This statistic reveals that the majority of students struggle with problem-solving.

The results of the analysis showed that self-regulated learning had no positive effect on students' mathematical problem-solving ability at SMA YP PGRI 3 Makassar. It was indicated by a t-calculated value of 5.675 and a significance value of 0.962 and (b1) value of 0.007 .

This finding is in contrast to that of Fadlelmula et al. (2014); Losenno et al. (2020) who found that self-regulated learning and students' problem-solving ability had a linear correlation. Furthermore, organizing a learning environment, according to (Fatih et al., 2020), is an ability that leads to good self-regulated learning. The development of self-regulation can be supported by various factors that exist around students such as teachers, parents, the environment, and the students' basic abilities. However, student self-regulation can be hampered by the use of conventional lecturing methods in the classroom which cannot engage students actively in learning and in acquiring knowledge from the process. Therefore, it appears as if problem-solving ability could not affect students' self-regulated learning.

\section{Problem-solving ability of students with high self-regulation}

During the preparation stage, the subject began the problem-solving process by reading the question given, followed by determining what was known and asked in the task. Then, the subject collected information needed to solve the problem. The subject appeared to be well prepared, responsible and confident, in line with the opinion of most researchers that students who have high self-regulation are able to set learning goals and task achievement (Granberg et al., 2021; Pintrich, 2017). After collecting the information, the subject started to explore mathematical concepts relevant to the problem by analyzing what was known in the problem, and finally developed an idea, a concept, or a way that was considered appropriate to solve the problem.

Yaniawati et al. (2019) describes students with high self-regulation as individuals who are proactive in finding and connecting background knowledge with the problem to be solved. Students who have good self-regulated learning are aware of the knowledge they are about to acquire, discover their strengths and weaknesses (metacognitive), are motivated to learn, and effectively use and monitor strategies to pursue learning goals (Hutchinson, 2013; Losenno et al., 2020).

Since the subject could not immediately solve the given problem, the subject seemed to think hard and imagine further ways to solve the problem. Problem-solving and selfregulation are two interrelated concepts of mathematics education (Yaniawati et al., 2019). Furthermore, Yaniawati et al. (2019) explains that problem-solving is a part of mathematics in which selfregulated learning is most obviously seen.

The following is a problemsolving procedure demonstrated by one of the participants who had a high problem-solving score. The student's initial step was to combine two- 
dimensional figures with the same area, then compare each known area of the figure using an example to discover the area of the figure. Figure 1 is an illustration of the student's solution to the problem.



Figure 1. Result of problem solving subject 1

At preparation stage, based on the results of interviews conducted by researchers and subject 1 , it is concluded that Subject 1 demonstrated how to solve the problem by locating the same shape and area in Tangrams I, II, III, and IV. Subject 1 discovers tangrams I = IV, III = VI = VII, and II = $\mathrm{V}$, suppose that the smallest area is $1 \mathrm{~cm} 2$. Subject 1 reasoned that the known tangrams could be formed from several smaller tangrams. For example, the area of the tangram I was equal to the area of four tangrams II.

After the preparation stage, the subject had to go through the contemplating stage or to pause for a moment to think, caused by the feeling of boredom. To get rid of boredom, the subject performed activities that have nothing to do with the problem-solving and during this period, the subject refused to think about what steps to take next. From these descriptions, it is clear that the subject demonstrated high motivation during the problem-solving process. There are several forms of emotion that can be identified, such as trying to think of the next steps to solve the problem even if the subject had to stop occasionally because of boredom. In line with this statement, recent research in the development of educational psychology shows that children's emotions and motivation and executive function are all involved in children's self-regulation and learning processes (Viglas, 2017).

At reflection stage, interview results show that Subject 1 struggled and became perplexed when it came to developing new problem-solving techniques. Subject 1 almost gave up but finished the answer sheet in 30.02 minutes.

The next stage that the subject performed was the stage of imagination. At this stage, the subject started thinking of the solution by connecting some of the mathematical concepts that have been found before by remembering and trying. In line with the opinion of Spielberg et al. (2019), boredom occasionally occurs when the child's self-awareness increases as the main cognitive capacity matures so that the child focuses on task demands, anticipates consequences for actions, inhibits inappropriate responses, and initiates appropriate tactics and strategies for achieving goals.

Furthermore, the imajination stage, based on the results of interviews conducted by researchers and subject 1 , it is concluded that Subject 1 tried to find another form of the known tangram arrangement, but it was difficult. Subject 1 was a little desperate and thought about finding a way out of the problem. Then, Subject 1 thought that by arranging Tangrams II, III, VI and VII, they could form a new triangle.

The subject was able to explain the problem-solving process well (orally and writing). An important skill for future school success from kindergarten is the achievement of literacy (Schmitt 
et al., 2017). Venn \& Jahn defines selfregulation as the number one precursor to literacy acquisition (Murphy, 2012). Language or literacy affects the ability to solve a problem (Rossi \& Carberry, 2020). (Chow et al., 2020) argue that language is an important component of social interaction, or it can also be said that social interaction can improve language development.

Poor children's social skills exacerbate them, not only from the social benefits of positive peer relationships but also from the benefits of language derived from social interactions (Chow et al., 2020). Vygotsky determines that literacy development is an integral aspect of self-regulated learning in which children are able to self-regulate in the future. He believes that through spoken language, children can promote the development of skills needed in academics, which have a unique influence on reading and writing (Bodrova et al., 2013). According to Vygotsky, language acquisition is a basic ability that children must have because language facilitates the acquisition of other abilities and support the transformation of many mental functions (Bodrova et al., 2013).

After going through the imagination stage where the subject attempted to find ideas to solve the problem, the subject did trial and error, rethought and sought the connection between the previously found mathematical concepts with the problem to be solved. At this stage, the subject found ideas to solve the problem at once. Furthermore, by linking these ideas, the subject finally found the solution.

Problem-solving is an effective tool for developing individual abilities, accelerating children's development, supporting the development of self- regulated learning abilities and selfconfidence, and helping children find alternative solutions to problems as they develop and gain experience (Aydoğan \& Özyürek, 2020). By Çiftci \& Bildiren (2019) suggests that metacognitive awareness, perceptions of problemsolving and the need to develop ideas are significantly related to one another. The concept of the need to develop ideas is considered to take place in the cognitive and affective domains, especially in the context of everyday problem-solving activities (Aydoğan \& Özyürek, 2020).

\section{Problem-solving ability of students with low self-regulation}

During the preparation stage, the subject read the problem repeatedly and looked hopeless, the subject seemed to give up and occasionally shook his head indicating his inability to continue the problem-solving process.

The cognitive process at the beginning of problem-solving is that the subject experienced anxiety. The subject showed a tense face and commented that the test question was difficult, even though he had not seen the overall test. During the questionmaking process, many students took a breath, massaged their foreheads, gave tired eyes, complained, frowned, went back and forth to the toilet and scribbled paper but could not find solutions to the given test. This is in accordance with the symptoms of anxiety mentioned by Andrea et al. (2020) which consists of two categories, namely physical symptoms such as fatigue, headache, dry mouth, cold sweat, excessive sweating etc. and psychological symptoms such as panic or fear, worry, the desire to run away or avoid it altogether, the inability to remember the material studied and so on. 
The next process carried out by the subject was to choose a question that is considered easy, try various ways to create a new tangram arrangement with a unique shape. The following is the tangram obtained by the subject (See Figure 2).

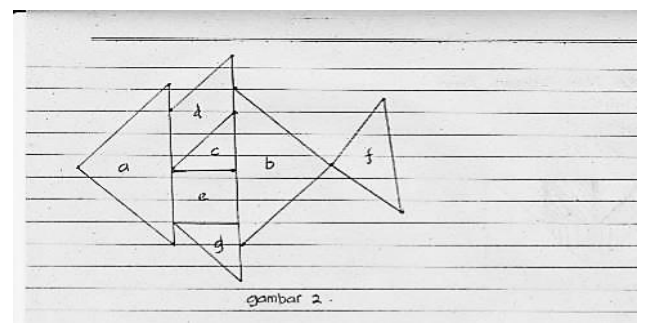

Figure 2. Result of Problem Solving Subject 2

The tangram arranged by the subject resembles a fish although it took a very long time for him to compose this form. Even so, the subject was able to describe the reasons for arranging the tangram with a unique shape. The arguments given make sense and are supported by several examples of different shapes.

Furthermore, based on the findings of the interviews with Subject 2 , it was determined that the problemsolving process did not have a dead end because the subject was able to answer the question smoothly. Furthermore, the cognitive process carried out by the subject was quite visible, namely the subject planned the right solution to solve the problem, formulated planning strategies and divided the time as best as possible in solving the problem.

From the qualitative analysis above, it can be concluded that there was an anomaly in this study where 1 student with low self-regulated learning obtained a high problem-solving score. This happens because the student had a good understanding of the question given, even though he showed symptoms of anxiety at the beginning of the problem-solving process. However, after trying to calm down, the subject was finally able to find an interesting solution to the problem. This finding is based on the statement of Yuen \& Goh (2020) stating that understanding is the level of ability that expects respondents to be able to understand a meaning or a concept, situations and facts that they know. Therefore, if a student does not have an understanding of the context of a problem, then he or she cannot understand the whole meaning or concept of the problem, which results in the inability to solve the problem or the inability to find a solution to the problem. Students sometimes perceive and explain basic concepts or events differently from what they learn (Neidorf et al., 2020). In fact, students assume that their knowledge is scientifically correct. This has led them to develop several alternative concepts (Adadan \& Yavuzkaya, 2018). The scientific definition in question is the information that makes sense and logically embedded in the students' concept learning systems (Mete, 2020).

The findings and discussion above suggest that students with poor selfregulated learning ability can achieve excellent problem-solving scores. This finding is backed by qualitative analysis, which clearly identifies the phenomenon's cause and effect. This has a favorable impact on the future development of student learning processes, as teachers are expected to focus more on studying student features and psychology during a pandemic.

\section{CONCLUSION AND SUGGESTION}

Based on the findings of this study, it can be concluded that there was no correlation between self-regulated learning and mathematical problemsolving ability of students i XI SMA YP 
PGRI 3 Makassar. The cognitive processes high self-regulated students were more likely to have good literacy, good metacognitive awareness, proactive in finding the connection between concepts that had been learned. However, these students showed a tendency to be inflexible. On the other hand, students with low self-regulation tended to be more flexible in using problem-solving strategies, but more anxious in the beginning of the problem-solving. In addition, these students got difficulties on expressing their opinions.

There were some challenges in carrying out this study, including: (1) a small number of research subjects, which means that the characteristics of the subjects do not vary and are less appealing; (2) limited access to information on research subjects' data, which means that the subject's family background and living environment cannot be identified; (3) The instrument designed to assess students' problemsolving skills focused solely on geometric math questions, limiting students' capacity to exhibit their proficiency in geometric math problems. As a result, future researchers are expected to be able to broaden the range of research subjects so that they can discover the features of various and unique research subjects. They must also gain access to more detailed research subjects' information and create more complex research instruments in order to assess students' mathematical problem-solving abilities in general.

\section{REFERENCES}

Adadan, E., \& Yavuzkaya, M. N. (2018). Examining the progression and consistency of thermal concepts: a cross-age study.
International Journal of Science

Education, 40(4), 371-396. https://doi.org/10.1080/09500693. 2018.1423711

Aydoğan, Y., \& Özyürek, A. (2020). Journal of History Culture and Art Research ( ISSN: 2147-0626) The Relationship between Problem-Solving Skills and Memory Development in Preschool Children. 9(3), 43-54. https://doi.org/10.7596/taksad.v9i 3.1988

Baars, M., van Gog, T., de Bruin, A., \& Paas, F. (2017). Effects of problem solving after worked example study on secondary school children's monitoring accuracy. Educational Psychology, 37(7), 810-834. https://doi.org/10.1080/01443410. 2016.1150419

Bodrova, E., Germeroth, C., \& Leong, D. J. (2013). Play and selfregulation: lessons from Vygotsky. American Journal of Play, 6(1), 111-123.

Cai, R., Wang, Q., Xu, J., \& Zhou, L. (2020). Effectiveness of Students' Self -Regulated Learning during the COVID-19 Pandemic. Sci Insigt, 34(1), 175-182. https://doi.org/10.15354/si.20.ar01 1.Author

Chow, J. C., Cunningham, J. E., \& Wallace, E. S. (2020). Interactioncentered model of language and behavioral development. In Handbook of Research on Emotional and Behavioral Disorders (pp. 83-95). Routledge.

Çiftci, S., \& Bildiren, A. (2020). The effect of coding courses on the cognitive abilities and problemsolving skills of preschool children. Computer Science Education, 30(1), 3-21. 
DOI: https://doi.org/10.24127/ajpm.v10i2.3538

https://doi.org/10.1080/08993408. 2019.1696169

Creswell, J. W. (2017). Research design: Qualitative, quantitative, and mixed methods approaches. Sage publications.

Fadlelmula, F. K., Cakiroglu, E., \& Sungur, S. (2014). Developing a structural model on the relationship among motivational beliefs, self-regulated learning strategies, and achievement in mathematics. International Journal of Science and Mathematics Education, 13(6), 1355-1375.

https://doi.org/10.1007/s10763013-9499-4

Fatih, F. D., Suharini, E., \& Sanjoto, T. B. (2020). Self-Regulation and Problem Solving Ability on Geography Basic Knowledge Materials Using the 7E-Learning Cycle Model. International Conference on Science and Education and Technology (ISET 2019), 229-233. Atlantis Press. https://doi.org/https://doi.org/10.2 991/assehr.k.200620.045

Gnaldi, M., Bacci, S., Kunze, T., \& Greiff, S. (2020). Students' Complex Problem Solving Profiles. Psychometrika, 85(2), 469-501.

https://doi.org/10.1007/s11336020-09709-2

Granberg, C., Palm, T., \& Palmberg, B. (2021). A case study of a formative assessment practice and the effects on students' selfregulated learning. Studies in Educational Evaluation, 68, 100955.

https://doi.org/10.1016/j.stueduc.2 020.100955

Hacker, D. J., \& Bol, L. (2019). Calibration and self-regulated learning: Making the connections (J. Dunlosky \& K. A. Rawson (Ed.)). The Cambridge handbook of cognition and education ( $\mathrm{p}$. 647-677). Cambridge University Press.

https://doi.org/https://doi.org/10.1 017/9781108235631.026

Hasbullah, H., \& Sajiman, S. U. (2020).

The Differences Of Cognitive Style Fields-Independent And Dependent On Students' Mathematical Problem Solving Abilities. AKSIOMA: Jurnal Program Studi Pendidikan Matematika, 9(2), 387-394. https://doi.org/10.24127/ajpm.v9i2 .2778

Hutchinson, L. R. (2013). Young children's engagement in selfregulation at school (Doctoral dissertation, University of British Columbia).

https://doi.org/10.14288/1.0073717

Kim, S., Choe, I., \& Kaufman, J. C. (2019). The development and evaluation of the effect of creative problem- solving program on young children' $\mathrm{s}$ creativity and character. Thinking Skills and Creativity, 33, 100590. https://doi.org/10.1016/j.tsc.2019. 100590

Lai, C., \& Hwang, G. (2016). Computers \& Education A selfregulated fl ipped classroom approach to improving students , learning performance in a mathematics course. Computers \& Education, 100, 126-140. https://doi.org/10.1016/j.compedu. 2016.05.006

Li, J., Yang, Z., Qiu, H., Wang, Y., Jian, L., Ji, J., \& Li, K. (2020). Anxiety and depression among general population in China at the peak of the COVID-19 epidemic Preventing suicide in the context 
DOI: https://doi.org/10.24127/ajpm.v10i2.3538

of the COVID-19 pandemic. World Psychiatry, 19(2), 249. https://doi.org/10.1002/wps.20758

Lo, C. K., \& Hew, K. F. (2020). A comparison of flipped learning with gamification, traditional learning, and online independent study: the effects on students' mathematics achievement and cognitive engagement. Interactive Learning Environments, 28(4), 464-481.

https://doi.org/10.1080/10494820. 2018.1541910

Losenno, K. M., Muis, K. R., Munzar, B., Denton, C. A., \& Perry, N. E. (2020). The dynamic roles of cognitive reappraisal and selfregulated learning during mathematics problem solving: A mixed methods investigation. Contemporary Educational Psychology, 61(April), 101869. https://doi.org/10.1016/j.cedpsych. 2020.101869

Maldonado Moscoso, P. A., Anobile, G., Primi, C., \& Arrighi, R. (2020). Math Anxiety Mediates the Link Between Number Sense and Math Achievements in High Math Anxiety Young Adults. Frontiers in Psychology, 11(May), $1-12$.

https://doi.org/10.3389/fpsyg.2020 .01095

Mete, P. (2020). 11th Grade Students' Understanding Level of Gases in terms of Some Chemical Variables and the Determination of Alternative Conceptions. Science Education International, 31(4), 334-347. https://doi.org/10.33828/sei.v31.i4.2

Murphy, K. P. (2012). Machine Learning - A Probabilistic Perspective - Table-of-Contents. The MIT Press, 1049.
Neidorf, T., Arora, A., Erberber, E., \& Tsokodayi, Y. (2020). An Introduction to Student Misconceptions and Errors in Physics and Mathematics. In Student Misconceptions and Errors in Physics and Mathematics (pp. 1-10). Springer, Cham.

Owusu-Fordjour, C., Koomson, C. K., \& Hanson, D. (2020). European Journal of Education Studies THE IMPACT OF COVID-19 ON LEARNING -. European Journal of Education Studies, 7(3), 88101.

https://doi.org/10.5281/zenodo.37535 86

Özdin, S., \& Bayrak Özdin, Ş. (2020). Levels and predictors of anxiety, depression and health anxiety during COVID-19 pandemic in Turkish society: The importance of gender. International Journal of Social Psychiatry, 66(5), 504-511. https://doi.org/10.1177/002076402 0927051

Panadero, E., \& Brown, G. T. (2017). Teachers' reasons for using peer assessment: positive experience predicts use. Journal of Psychology of Education, 32(1), 133-156. https://doi.org/10.1007/s10212015-0282-5

Pascoe, M. C., Hetrick, S. E., \& Parker, A. G. (2020). The impact of stress on students in secondary school and higher education education. International Journal of Adolescence and Youth, 25(1), 104-112. https://doi.org/10.1080/02673843. 2019.1596823

Pekrun, R. (2017). Emotion and Achievement During Adolescence. Child Development Perspectives, 11(3), 215-221. 
DOI: https://doi.org/10.24127/ajpm.v10i2.3538

https://doi.org/10.1111/cdep.12237

Pintrich, P. R. (2017). Issues in SelfRegulation Theory and Research. The Journal of Mind and Behavior, 21(1), 213-219. https://doi.org/https://www.jstor.or $\mathrm{g} / \mathrm{stable} / 43853917$

Rossi, M. N., \& Carberry, A. R. (2020). Elements of Good ProblemSolving Tasks in Thinking Classrooms. American Society for Engineering Education, 6.

Schmitt, S. A., Geldhof, G. J., Purpura, D. J., Duncan, R., \& McClelland, M. M. (2017). Examining the relations between executive function, math, and literacy during the transition to kindergarten: a multi-analytic approach. Journal of Educational Psychology, 109(8), 1120. https://doi.org/10.1037/edu0000193

Smith, J. M., \& Mancy, R. (2018). Exploring the Relationship Between Metacognitive and Collaborative Talk During Group Mathematical Problem-SolvingWhat Do We Mean by Collaborative Metacognition? Research in Mathematics Education, 20(1), 14-36. https://doi.org/10.1080/14794802. 2017.1410215

Spielberg, S., Tulsyan, A., Lawrence, N. P., Loewen, P. D., \& Bhushan Gopaluni, R. (2019). Toward selfdriving processes: A deep reinforcement learning approach to control. AIChE Journal, 65(10). https://doi.org/10.1002/aic.16689

van Gog, T., Hoogerheide, V., \& van Harsel, M. (2020). The Role of Mental Effort in Fostering SelfRegulated Learning with ProblemSolving Tasks. Educational Psychology Review, 32(4), 10551072. https://doi.org/10.1007/s10648- 020-09544-y

Viglas, M. (2017). Effects of a mindfulness-based program on young children's self-regulation, prosocial behavior and hyperactivity. Journal of Child and Family Studies, 27(4), 11501161.

https://doi.org/10.1007/s10826017-0971-6

Violanti, M. T., Kelly, S. E., Garland, M. E., Christen, S., Violanti, M. T., Kelly, S. E., Garland, M. E., Christen, S., Violanti, M. T., Kelly, S. E., Garland, M. E., \& Christen, S. (2018). Instructor clarity, humor, immediacy, and student learning: Replication and extension. Communication Studies, 69(3), 251-262. https://doi.org/10.1080/10510974. 2018.1466718

Xiantong, Y., Mengmeng, Z., Xin, S., Lan, H., \& Qiang, W. (2019). Regional educational equity: A survey on the ability to design scientific experiments of sixthgrade students. Journal of Baltic Science Education, 18(6), 971985.

https://doi.org/10.33225/jbse/19.1 8.971

Yaniawati, R. P., Kartasasmita, B. G., \& Saputra, J. (2019). E-learning assisted problem based learning for self-regulated learning and mathematical problem solving. Journal of Physics: Conference Series, 1280(4). https://doi.org/10.1088/17426596/1280/4/042023

Yuen, A., \& Goh, S. (2020). Oxford Review of Education Learning cultures : understanding learning in a school-university partnership. Oxford Review of Education, 1-16. https://doi.org/10.1080/03054985. 2020.1825368 